\title{
THE COATING OF A NiTi ALLOY HAS A GREATER IMPACT ON THE MECHANICAL PROPERTIES THAN THE ACIDITY OF SALIVA
}

\author{
OPLAŠČENJE NiTi ZLITINE IMA VEČJI VPLIV NA NJENE \\ MEHANSKE LASTNOSTI KOT KISLOST SLINE
}

\author{
Darko Pop Acev ${ }^{1}$, Visnja Katic ${ }^{1}$, Gianluca Turco ${ }^{2}$, Luca Contardo ${ }^{2}$, Stjepan Spalj ${ }^{1}$ \\ ${ }^{1}$ University of Rijeka, School of Medicine, Department of Orthodontics, Croatia \\ ${ }^{2}$ University of Trieste, School of Dentistry, Department of Medical, Surgical and Health Sciences, Trieste, Italy \\ darko-pop-acev@hotmail.com
}

Prejem rokopisa - received: 2017-08-04; sprejem za objavo - accepted for publication: 2018-02-15

doi: $10.17222 /$ mit. 2017.133

\begin{abstract}
The aim of this study was to evaluate the influence of the acidity of saliva on changes to the surface roughness, friction and microhardness of NiTi alloys with various coatings. Three types of commercially available NiTi archwires: uncoated, rhodium coated and nitrified (dimension $0.508 \times 0.508 \mathrm{~mm}, 10 \mathrm{~cm}$ long) were immersed in $10 \mathrm{~mL}$ of artificial saliva with the $\mathrm{pH}$ ranging from 4.8 to 6.6 for a period of $28 \mathrm{~d}$. Surface roughness, friction and microhardness were analyzed and compared to the unexposed as-received wires. These mechanical properties were influenced by the wire coating with a moderate-to-high effect size $\left(p \leq 0.005 ; \eta^{2}=0.132-0.309\right)$. The uncoated wire had a lower maximum roughness depth after exposure to $\mathrm{pH} 6.6$ and 5.5 than the unexposed wire $\left(p=0.026 ; \eta^{2}=0.346\right)$. The friction was significantly increased only in the rhodium-coated $\mathrm{NiTi}$ at $\mathrm{pH}$ 4.8 compared to the lower acidities and the unexposed wire $\left(p=0.005 ; \eta^{2}=0.437\right)$. No correlation was found between $\mathrm{pH}$, surface roughness, friction and microhardness, respectively. The coating of a NiTi alloy has a greater impact on the mechanical properties than the acidity does. A rhodium coating makes the alloy harder, induces a rougher surface and more friction. Nitrification does not alter the alloy as much. The relation between acidity and mechanical properties is not linear. A high acidity of 4.8 induces a high friction, but only in rhodium-coated NiTi. A lower acidity does not change the friction significantly.

Keywords: nickel-titanium, surface roughness, friction, $\mathrm{pH}$

Cilj študije je bil ovrednotiti vpliv kislosti sline na spremembe površinske hrapavosti, trenja in mikrotrdote biokompatibilne $\mathrm{NiTi}$ zlitine z različnimi oplaščenji. Avtorji so za svoje preiskave uporabili tri vrste komercialno dosegljivih NiTi ortodontskih pritrjevalnih žic: neoplaščeno, oplaščeno z rodijem in nitrificirano (dimenzij $0,508 \mathrm{~mm} \times 0,508 \mathrm{~mm}$, dolžine $10 \mathrm{~cm}$ ). Žice so 28 dni potapljali v $10 \mathrm{ml}$ umetne sline s pH vrednostjo med 4,8 in 6,6. Nato so izvedli analize površinske hrapavosti, trenja in mikrotrdote $\mathrm{v}$ slino namočenih žic in jih primerjali z nenamočenimi izhodnimi žicami. Na mehanske lastnosti je imelo oplaščenje žic zmeren do znaten vpliv $\left(p \leq 0.005 ; \eta^{2}=0,132-0,309\right)$. Neoplaščena žica je imela manjšo maksimalno globino hrapavosti po izpostavitvi $\mathrm{pH} 6,6$ in 5,5 kot žica, ki slini ni bila izpostavljena $\left(p=0,026 ; \eta^{2}=0,346\right)$. Trenje se je znatno povečalo samo pri z rodijem oplaščeni NiTi žici pri pH 4,8 v primerjavi z manjšimi kislostmi in pri s slino neizpostavljeni žici $\left(p=0,005 ; \eta^{2}=0,437\right)$ Avtorji niso našli nobene povezave med $\mathrm{pH}$, površinsko hrapavostjo, trenjem in mikrotrdoto. Oplaščenje NiTi zlitine ima večji vpliv na mehanske lastnosti kot kislost. Oplaščenje z rodijem naredi zlitino tršo, inducira bolj grobo površino in poveča trenje. Nitrifikacija bistveno ne spremeni zlitine. Zveza med kislostjo in mehanskimi lastnostmi ni linearna. Velika kislost 4,8 inducira trenje, vendar samo pri z rodijem oplaščenih NiTi žicah. Manjša kislost pomembno ne spremeni trenja.

Ključne besede: nikelj-titan, površinska hrapavost, trenje, $\mathrm{pH}$
\end{abstract}

\section{INTRODUCTION}

Tooth movements during an orthodontic treatment can be compromised by the frictional forces that occur between the brackets and the archwire. This frictional resistance depends on the material's composition and structure. ${ }^{1-3}$ The nickel-titanium (NiTi) alloy, due to its great elasticity and high springback, is one of the most used biomaterials in orthodontics. ${ }^{4-6}$ Saliva can induce intra-oral corrosion of dental biomaterials, compromising their mechanical properties. ${ }^{7,8}$ The degree of the corrosion may depend on the saliva's composition and acidity. ${ }^{9}$ The aim of our study is to evaluate the influence of different $\mathrm{pH}$ acidities for possible changes in the surface roughness, friction and microhardness of NiTi alloys with various coatings. It was hypothesized that higher acidity would induce greater corrosion, which would result in an increase of the surface roughness and friction, while the microhardness would decrease. The greatest change would be observed in the rhodium coated and the least in the nitrified NiTi alloy.

\section{EXPERIMENTAL PART}

Tests were conducted in laboratory conditions. Three types of commercially available NiTi archwires (dimensions: $0.508 \mathrm{~mm} \times 0.508 \mathrm{~mm}$ i.e. 0.020 " $\times 0.020$ "; composition: $\mathrm{Ni}=50.4 \%$ and $\mathrm{Ti}=49.6 \%$ ) were tested: an uncoated one (BioForceSentalloy ${ }^{\circledR}$ ), nitirified (IonGuard ${ }^{\circledR}$ ) and rhodium coated (High Aesthetic ${ }^{\circledR}$; (Dentsply GAC, Bohemia, USA). Specimens $10 \mathrm{~cm}$ long were first rinsed with alcohol, cleaned in an ultrasonic bath and then immersed into plastic tubes with $10 \mathrm{~mL}$ of artificial 
saliva prepared using the Tanni-Zucchi method (composition: $1.5 \mathrm{~g} / \mathrm{L} \mathrm{KCl} ; 1.5 \mathrm{~g} / \mathrm{L} \mathrm{NaHCO} 3 ; 0.5 \mathrm{~g} / 1 \mathrm{NaH}_{2} \mathrm{PO}_{4} \mathrm{X}$ $\mathrm{H}_{2} 0 ; 0.5 \mathrm{~g} / \mathrm{L} \mathrm{KSCN} ; 0.9 \mathrm{~g} / \mathrm{L}$ lactic acid), which represents a normal oral environment condition. ${ }^{10}$ TanniZucchi saliva contains lactic acid which represents the byproducts released by oral bacteria in the oral cavity. ${ }^{11}$ The samples were incubated in a water bath at $37{ }^{\circ} \mathrm{C}$ for a period of $28 \mathrm{~d}$. The $\mathrm{pH}$ was set to $(4.8,5.1,5.5$ and 6.6) by the addition of lactic acid and $\mathrm{NaOH}$. After completion of the immersion protocol, the wire specimens were taken for an analysis of the mechanical properties. The distal, straight part of archwire $2.5 \mathrm{~cm}$ long was used for the measurement of surface roughness and friction and the rest for the microhardness testing. As-received samples that were not immersed into artificial saliva served as a control. Six samples of each archwire type in each condition were analyzed.

\section{Measurement of surface roughness}

Surface geometry was analysed using the contact profilometer Talysurf CLI 1000 (Taylor Hobson Ltd., Leicester, United Kingdom). Traced profiles of the real surface were acquired with a diamond stylus of $5-\mu \mathrm{m}$ radius. During the measurement, the stylus was moved at a constant speed across the samples with a measuring force of $1.3 \mathrm{mN}$. Three variables, i.e., roughness average $\left(R_{\mathrm{a}}\right)$, maximum height $\left(R_{\mathrm{z}}\right)$ and maximum roughness depth $\left(R_{\max }\right)$, were measured on three profiles of each specimen, using a Gaussian filter with a cut-off value of $0.8 \mathrm{~mm}$ and an evaluation length of $4 \mathrm{~mm}$. The arithmetic mean of the measurements was used for statistical analysis. Two readings were performed on each sample for testing the reproducibility.

\section{Friction test}

Three stainless-steel brackets for maxillary dental arch (lateral incisor, canine and first premolar) Victory Series MBT 0.022" (3M Unitec, Monrovia, USA) were bonded to a previously air-polished hard plastic plate with $5 \mathrm{~mm}$ distance between each bracket. Light cured adhesive Transbond XT (3M Unitec, Monrovia, USA) was used for fixture of the brackets. To prevent additional friction during movement they were positioned parallel by introducing straight 0.021 " $\times 0.025$ " stainless steel wire Unitec Stainless Steel (3M Unitec, Monrovia, SAD) into slots. A uniform pressure was obtained by fixing the wire into the bracket slots with elastic ligatures Alastik (3M Unitek, Monrovia, SAD). The plate with the brackets was fixed in a universal material testing machine Sun 500 (Galdabini, Cardano al Campo, Italy). The friction between the brackets and the wire was measured in dry conditions with a speed of $5 \mathrm{~mm} / \mathrm{min}$ for $60 \mathrm{~s}$ and a loading force of $100 \mathrm{~N}$. Each specimen was measured twice, with highest friction noted in Newtons and arithmetic mean of these two measurements taken as a friction value.

\section{Microhardness}

The wire microhardness was measured on a Leica VMHT MOT (Walter Uhl, Asslar, Germany) using the Vickers method by indenting diamond four-sided pyramid with a tip angle of $136^{\circ}$ and a mass of $100 \mathrm{~g}$ $(1 \mathrm{~N})$ for $15 \mathrm{~s}$. The hardness, according to Vickers (HV), was measured using the equation $\mathrm{HV}=0.0018544 \times$ $L / d^{2}$, where $L$ is loading in grams and $d$ is the arithmetic mean of the calculated lengths of two diagonals on the indented four-sided pyramid base in millimetres. The length of the diagonals was measured by microscope magnifier of 50×. Each wire sample was tested twice and every measurement was read twice. The arithmetic mean was used for the analysis. For the calculation of the sample size, data from a pilot study was used. Assuming that the difference in hardness between two experimental conditions would be 40, with standard deviation of 20 in both conditions with a power of $80 \%$ and a level of significance $\alpha=0.05$, a minimum of five samples per group was needed. The same sample size was needed for the friction tests assuming that friction would differ $0.2 \mathrm{~N}$ with standard deviation of 0.1 in each experimental condition. The assumed difference between two experimental conditions in roughness average would be 0.021 with a standard deviation of 0.005 in the first and 0.013 in the second condition with a power of $80 \%$ and a significance $\alpha=0.05$ a required size of five samples per group was necessary. The calculations were made in statistical software MedCalc 14.8.1 (MedCalc Software bvba, Belgium).

The difference in mechanical properties between different types of wires, before and after the exposure to different $\mathrm{pH}$ values, was assessed with one-way and two-way analyses of variances (ANOVA) with Students-Newman-Keuls post-hoc tests. The effect size was assessed by $\eta^{2}$. The Cohen criteria were used for interpretation: $\eta^{2}=0.02-0.13=$ low effect size, $0.13-0.26$ $=$ moderate and $>0.26=$ high effect size. Pearson correlations were used to analyse the presence of a linear correlation between $\mathrm{pH}$ and surface roughness, friction and microhardness, as well as between microhardness and friction. The reproducibility of the measurements was estimated by intraclass correlation coefficient and quantified by $95 \%$ confidence interval (CI), while the difference in the measurements were tested with t-test for dependent samples. Statistical software IMB SPSS 22 (IBM Corp, Armonk, USA) was used.

\section{RESULTS}

\section{Surface roughness}

Surface-roughness measurements at two points on the same sample indicated significant agreement in $R_{\mathrm{a}}, R_{\mathrm{z}}$ and $R_{\max }(\mathrm{ICC}=0.693-0.875 ; p<0.001)$ and excellent reproducibility of readings during measurement (ICC $=0.997-0.999 ; p<0.001)$. 

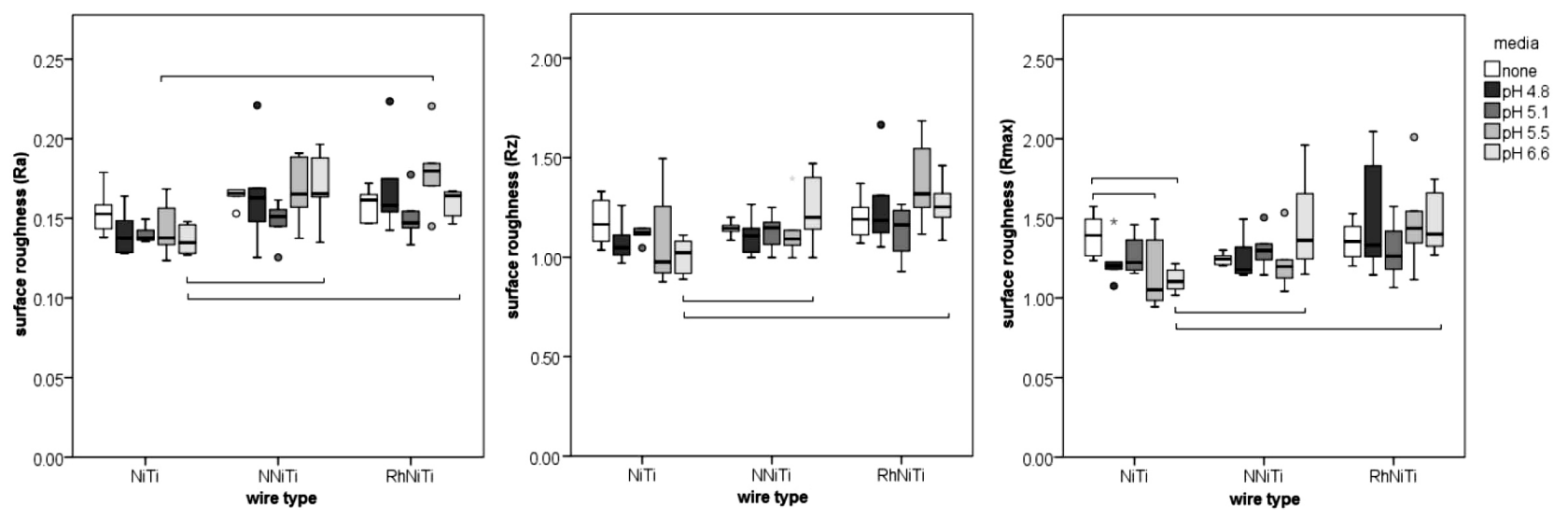

Figure 1: Surface roughness according to $\mathrm{pH}$ and surface coating

Two-way ANOVA demonstrated that Ra value of surface roughness is influenced by wire type $(\mathrm{p}<0.001$; $\eta^{2}=0.264 ;$ Figure 1), but not by acidity $(p=0.057$; $\eta^{2}=0.113$ ) nor by the combination of wire type and acidity $\left(p=0.376 ; \eta^{2}=0.105\right)$. Differences were detected at $\mathrm{pH}$ values of 5.5 and 6.6 . At $\mathrm{pH}$ of 5.5 the rhodium-coated wire had higher $R_{\mathrm{a}}$ than uncoated one $\left(p=0.021 ; \eta^{2}=0.401\right.$; Figure 1a). At $\mathrm{pH}$ value of 6.6 the rhodium-coated and nitrified wires had significantly higher $R_{\mathrm{a}}$ than the uncoated NiTi $\left(p=0.004 ; \eta^{2}=0.521\right)$.

The $R_{\mathrm{z}}$ value is related to wire type $(p<0.001$; $\left.\eta^{2}=0.190\right)$, but not to the acidity $\left(p=0.639 ; \eta^{2}=0.033\right)$ nor the combination of wire type and acidity $(p=0.086$; $\left.\eta^{2}=0.163\right)$. The rhodium-coated and nitrified wires had higher $R_{\mathrm{z}}$ than uncoated after exposure to $\mathrm{pH}$ of 6.6 ( $p=0.009 ; \eta^{2}=0.467$; Table 1b).

The $R_{\max }$ value was related to wire type ( $p=0.001$, $\left.\eta^{2}=0.162\right)$ as well as to the combination of wire type and acidity $\left(p=0.047 ; \eta^{2}=0.183\right)$. The uncoated wire had lower $R_{\max }$ after exposure to $\mathrm{pH} 6.6$ and 5.5 than the unexposed wire $\left(p=0.026 ; \eta^{2}=0.346\right.$; Figure 1c). At $\mathrm{pH}$ 6.6 the rhodium-coated and nitrified wires had higher $R_{\max }$ than the uncoated one $\left(p=0.014 ; \eta^{2}=0.418\right)$.

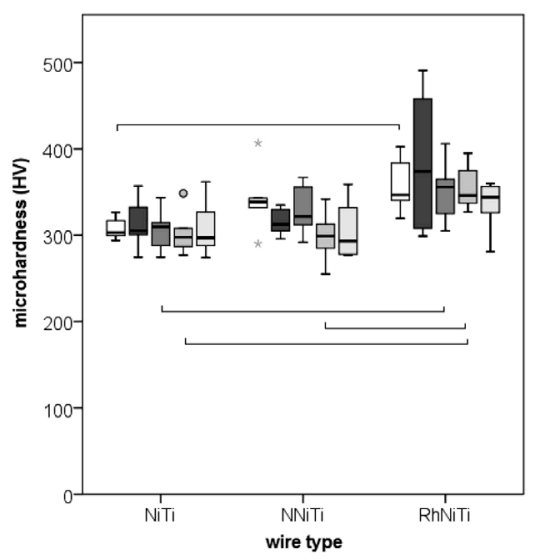

\section{Microhardness}

Measurements of the microhardness at two locations on the same wire indicated significant agreement (ICC $=0.672$ (95\% CI: 0.372-0.844); $p<0.001$ ), and two measurements did not differ significantly. The reproducibility of the two readings was very good ( $\mathrm{ICC}=0.856$; $p<0.001$ ).

Two-way ANOVA indicated that the wire type affects the microhardness $\left(p<0.001 ; \eta^{2}=0.309\right)$, but not acidity $\left(p=0.237 ; \eta^{2}=0.070\right)$ nor a combination of $\mathrm{pH}$ acidity and the wire type $\left(p=0.510 ; \eta^{2}=0.089\right)$. Generally, the rhodium-coated wire was harder than the nitrified and uncoated, but a significant difference was present mainly for the uncoated wire for several $\mathrm{pH}$ values (Figure 2a). There was no difference in the microhardness between the uncoated and nitrified orthodontic wires. (Figure 2a).

\section{Friction}

Friction measurements at two locations on the same wire show significant agreement ( $\mathrm{ICC}=0.559$ (95\% CI: $0.347-0.833) ; p<0.001)$, although two measurements differed significantly for an average of $0.09 \mathrm{~N}(p<0.05)$.

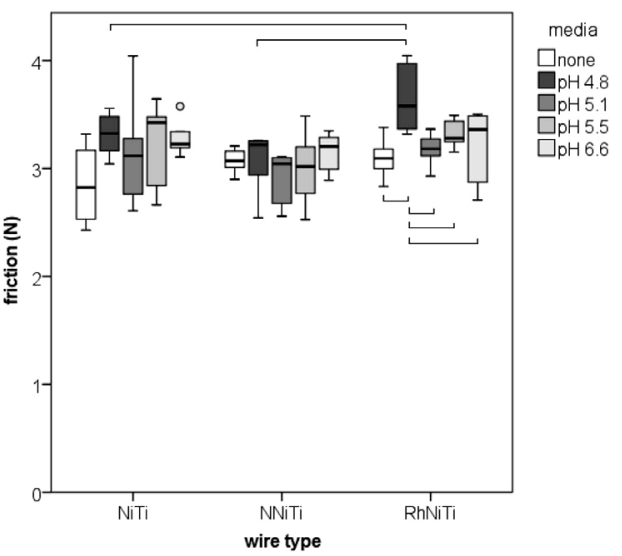

Figure 2: Microhardness and friction according to $\mathrm{pH}$ and surface coating 
The reproducibility of the readings was excellent $(\mathrm{ICC}=1.0 ; p<0.001)$.

Two-way ANOVA indicated that both wire type and acidity affect the friction $\left(p=0.005 ; \eta^{2}=0.132\right.$ and $\left.p=0.007 ; \eta^{2}=0.171\right)$, but their combination did not $\left(p=0.189 ; \eta^{2}=0.134\right)$.

Figure 2b shows that friction is significantly increased only in rhodium-coated $\mathrm{NiTi}$ at $\mathrm{pH} 4.8$ compared to other acidities $\left(p=0.005 ; \eta^{2}=0.437 ;\right)$. Also at $\mathrm{pH} 4.8$ the rhodium-coated NiTi has a higher friction than the nitrified and uncoated wire $\left(p=0.007 ; \eta^{2}=0.483\right)$. At higher $\mathrm{pH}$ values significant changes were not found among each type of coatings.

The Pearson correlation tests did not detect any significant correlation between the $\mathrm{pH}$ values and the microhardness, nor between the $\mathrm{pH}$ and the friction in any of the wire types. No correlation was reported between the microhardness and the friction.

\section{DISCUSSION}

The present research demonstrates that the effect of the acidity of saliva on the mechanical properties of NiTi alloys is modified by the alloy's coating. In fact, coating influences the mechanical properties more than the acidity.

The rhodium coating induces a rougher surface, more friction and makes the alloy harder. Nitrification does not alter the observed mechanical characteristics of the alloy so much, although the manufacturer advertises the opposite. A high surface roughness in the RhNiTi in comparison to other orthodontic archwires was reported previously. ${ }^{12}$ Some coatings, such as a titanium-oxide layer, which is a result from the oxidation process improves the corrosion resistance and friction behavior. ${ }^{13}$ The resistance in the orthodontic tooth movement is influenced directly by the type of the materials used. ${ }^{14,15}$ NiTi demonstrates the relatively high frictional coefficient and surface roughness, and low hardness, but its elastic characteristic makes it excellent for the levelling and alignment of the teeth. ${ }^{6,8}$ Differences in the friction that were detected between two measurements on the same wire could be attributed to the mild curving of the wire.

Although it was hypothesized that higher acidity would induce higher corrosion, which would be seen in increase of surface roughness, friction and decrease of microhardness it was not the case. No linear relationship between the level of acidity and the mechanical properties was seen. Acidity does not influence the hardness much, while a high acidity of 4.8 induces a high friction in RhNiTi. This could be due to the highest ion release, which the rhodium-coated wire is predisposed to due to rougher surface because coating is disrupted and porous; chemical composition of the surface also plays important role in corrosion processes. ${ }^{16-18}$ It was confirmed that the more acidic the salivary $\mathrm{pH}$ becomes, the corrosion gets accelerated, but a rougher surface does not predispose higher corrosion. ${ }^{19}$ Furthermore, when immersed into a more acid solution, the wire may become brittle due to the penetration of the hydrogen into the NiTi wire. ${ }^{20}$

The type of coating studied on the as-received samples revealed a higher elastic modulus and yield strength of the rhodium-coated wires during loading; however, no differences were found during unloading, i.e., upon recovery of the memory shape of the wires, which is important for clinical performance. ${ }^{21}$ The observed differences in mechanical properties were probably generated during different manufacturing conditions. Also, the small differences in the transformation of the crystal lattice were observed already for the as-received samples, and also were contributed to different manufacture procedures. ${ }^{22}$ The influence of the hydrogen absorption probably contributes to the observed changes in mechanical properties. ${ }^{20}$

No correlation between the surface roughness and friction has been found, and similar was reported previously. ${ }^{23}$ Frictional resistance does not directly correlate to the surface roughness, but it depends on the type of the material, as TMA wires which have bigger surface roughness than nickel-titanium wires have lower frictional resistance. ${ }^{24}$ Although others report that there could be an indirect correlation between these two parameters. ${ }^{25}$

\section{CONCLUSIONS}

The coating of NiTi alloy has a greater impact on the mechanical properties than acidity does. A rhodium coating makes the alloy harder, induces a rougher surface and more friction. Nitrification does not alter alloy as much. The relation between the acidity and the mechanical properties is not linear. A high acidity of 4.8 induces a high friction, but only in RhNiTi. A lower acidity does not change the friction.

\section{Acknowledgement}

This article has been supported by the project of Croatian Science Foundation "Immunological and regenerative implications of corrosion of dental materials in children and adolescents" (IP-2014-09-7500).

\section{REFERENCES}

${ }^{1}$ J. R. Bednar, G.W. Gruendeman, J. L. Sandrik, A comparative study of frictional forces between orthodontic brackets and archwires. Am J Orthod Dentofacial Orthop., 100 (1991), 513-522, doi:10.1016/ 0889-5406(91)70091-A

${ }^{2}$ C. A. Frank, R. J. Nikolai, A comparative study of frictional resistances between orthodontic bracket and archwire. Am. J. Orthod., 78 (1980), 593-609

${ }^{3}$ C. Bourauel, T. Fries, D. Drescher, R. Piletsch, Surface roughness of orthodontic wires via atomic force microscopy, laser specular reflectance and profilometry, Eur. J. Orthod., 20 (1998) 79-92 
${ }^{4}$ R. Schneevoigt, A. Haase, V. L. Eckardt, W. Harzerand, C. Bourauel, Laboratory analysis of superelastic NiTi compression springs, Med. Eng. Phys., 21 (1999), 119-125, doi:10.5405/jmbe.700

${ }^{5}$ F. Miura, M. Mogi, Y. Ohuraand, H. Hamanaka, The super-elastic property of the Japanese NiTi alloy wire for use in orthodontics, Am. J. Orthod. Dentofacial. Orthop., 90 (1986) 1-10, doi:10.1016/08895406(86)90021-1

${ }^{6}$ J. Ferčec, M. Kos, M. Brunčko, I. Anžel, B. Glišič, E. Marković, R. Rudolf, Comparison of NiTi orthodontic archwires and a determination of the characteristic properties, Mater. Tehnol., 48 (2014) 3, 99-104

${ }^{7}$ C. T. Kao, T. H. Huang, Variations in surface characteristics and corrosion behavior of metal brackets and wires in different electrolyte solutions, Eur. J. Orthod., 32 (2010), 555-560, doi:10.1093/ ejo/cjp146

${ }^{8}$ I. H. Liu, T. M. Lee, C. Y. Chang, C. K. Liu, Effect of load deflection on corrosion behavior of NiTi wire, J. Dent. Res., 86 (2007), 539-543, doi:10.1177/154405910708600610

${ }^{9}$ G. Bayramoğlu, T. Alemdaroğlu, S. Kedici, A. A. Aksüt, The effect of $\mathrm{pH}$ on the corrosion of dental metal alloys, J. Oral. Rehabil., 27 (2000), 563-575, doi:10.1046/j.1365-2842.2000.00549.x

${ }^{10}$ G. Tanni, F. Zucchi, Electrochemical measurement of the resistance to corrosion of some commonly used metals for dental prosthesis, Minerva Stomatol., 16 (1967), 710-3

${ }^{11}$ I. Demetrescu, B. Popescu, D. Ionita, I. Rau. Electrochemical behaviour of Ti and TiAIV in Tani-Zucchi artificial saliva, Mol. Cryst. Liq. Cryst., 418 (2004), 271-284

${ }^{12}$ V. D’Anto, R. Rongo, G. Ametrano, G. Spagnuolo, P. Manzo, R. Martina, S. Paduano, R. Valletta, Evaluation of surface roughness of orthodontic wires by means of atomic force microscopy, Angle Orthod., 82 (2012), 922-928, doi:10.2319/100211-620.1

${ }^{13}$ E. Espinar, J. M. Llamas, A. Michiardi, M. P. Ginebra, F. J. Gil, Reduction of Ni release and improvement of the friction behavior of $\mathrm{NiTi}$ orthodontic archwires by oxidation treatments, J. Mater. Sci Mater. Med., 22 (2011), 1119-1125, doi:10.1007/s10856-011-4292-9

${ }^{14}$ R. P. Kusy, J. O. Whitley, J. A. Gurgel, Comparisons of surface roughness and sliding resistance of 6 titanium-based or TMA-type archwires, Am. J. Orthod. Dentofacial Orthop., 126 (2004), 589-603, doi:10.1016/S0889540604005189

${ }^{15}$ M. R. Pacheco, W. C. Jansen, D. D. Oliveira, The role of friction in orthodontics, Dental Press J. Orthod., 17 (2012), 170-177, doi:10.1590/S2176-94512012000200028
${ }^{16}$ M. Iijima, T. Muguruma, W. Brantley, H. C. Choe, S. Nagakaki, S B. Alapati, I. Mizoguchi, Effect of coating on properties of aesthetic orthodontic nickel-titanium wires, Angle Orthod., 82 (2012), 319-325, doi:10.2319/021511-112.1

${ }^{17}$ F. C. Walah, C. Ponce de Leon, C. Kerr, S. Court, B. D. Barker, Electrochemical characterization of the porosity and corrosion resistance of electrochemically deposited metal coatings. Surf Coat Tech., 202 (2008), 5092-5102, doi:10.1016/j.surfcoat.2008.05.008

${ }^{18}$ V. Katic, L. Curkovic, M. U. Bosnjak, S. Spalj, Determination of corrosion rate of orthodontic wires based on nickel-titanium alloy in artificial saliva, Materialwiss. Werkst. 45 (2014), 99-105

${ }^{19}$ H. H. Huang, Y. H. Chiu, T. H. Lee, S. C. Wu, H. W. Yang, K. H. Su, C. C. Hsu, Ion release from NiTi orthodontic wires in artificial saliva with various acidities, Biomaterials., 24 (2003), 3585-3592, doi:10.1016/S0142-9612(03)00188-1

${ }^{20}$ K. Yokoyama, T. Ogawa, K. Asaoka, J. Sakai, M. Nagumo, Degradation of tensile strength of NiTi superelastic alloy due to hydrogen absorption in methanol solution containing hydrochloric acid, Mat. Sci. Eng. A 360 (2003), 153-159, doi:10.1177/1045389X11423427

${ }^{21}$ V. Katic, H. Otmacic Curkovic, D. Semenski, G. Barsic, K. Marusic, S. Spalj, Influence of surface layer on mechanical and corrosion properties of nickel-titanium orthodontic wires, Angle Orthod., 84 (2014) 6, 1041-1048

${ }^{22}$ V. Katić, V. Mandić, D. Ježek, G. Baršić, S. Špalj, Influence of various fluoride agents on working properties and surface characteristics of uncoated, rhodium coated and nitrified nickel-titanium orthodontic wires, Acta Odontol. Scand., 73 (2015) 4, 241-249, doi:10.3109/00016357.2014.980847

${ }^{23}$ P. Rudge, M. Sherriff, D. Bister, A comparison of roughness parameters and friction coefficients of aesthetic archwires, Eur. J. Orthod., 37 (2015), 49-55, doi:10.1093/ejo/cju004

${ }^{24}$ R. P. Kusy, J. Q. Whitley, M. J. Mayhew, J. E. Buckthal, Surface roughness of orthodontic archwires via laser sprectroscopy, Angle Orthod., 58 (1988), 33-45, doi:10.1043/0003-3219(1988)058<0033: SROOA $>2.0 . \mathrm{CO} ; 2$

${ }^{25}$ S. Choi, E. Y. Hwang, H. K. Park, Y. G. Park, Correlation between frictional force and surface roughness of orthodontic archwires: LFM analysis of Aws, Scanning, 37 (2015), 399-405, doi:10.1002/ sca. 21225 